\title{
Rendahnya asupan zat besi dan kepatuhan mengonsumsi tablet besi berhubungan dengan kejadian anemia pada ibu hamil di Wilayah Kerja Puskesmas I Kembaran, Banyumas
}

The relationship between nutrient intake and level of compliance in consuming iron tablet with incidence of anemia in pregnant women at work area of Puskesmas I Kembaran Banyumas

Ari Purwoko Widji Utomo ${ }^{1}$, Detty Siti Nurdiati ${ }^{2}$, Retna Siwi Padmawati ${ }^{3}$

\begin{abstract}
Background: One of the nutritional problems that frequently occur in pregnant women is anemia, which is the biggest problem of micronutrient and the most difficult to overcome in the world. Anemia occurs at all stages of the life cycle, more commonly attacked pregnant women and children. The cause of anemia is iron deficiency which is needed to the formation of a hemoglobin $(\mathrm{Hb})$. Defficiency of iron in the body is due to lack of consumption of food sources of iron and the non-compliance of pregnant women in consuming iron tablets. Supplementation of iron tablets and improvement of nutrient intake especially good source of iron is one of anemia prevention that has been done.

Objectives: To determine the relationship between nutrient intake and the level of compliance in consuming iron tablets with incidence of anemia in pregnant women at work area of Puskesmas I Kembaran Banyumas.

Methods: This was an observational study (survey) with a cross sectional design with 50 subjects of the third trimester pregnant women. The research used both quantitative and qualitative approaches.

Results: The percentage of anemia in pregnant women in this study was $56.0 \%$. The results of the multivariable analysis showed that only compliance-related iron tablets consumption significantly had relationship ( $p=0.001, R P=3.7,95 \% \mathrm{Cl}: 2.06-6.82)$ with the incidence of anemia in pregnant women. The high cost of animal food sources, the limitation of animal food sources diversity, and the dislike animal food sources consumption caused pregnant women choosing plant-based foods that where cheap and easily obtainable.

Conclusions: This study proved that the intake of nutrients, especially iron and compliance of pregnant women in consuming iron tablets was still be the cause of anemia in pregnant women. Therefore, it needs to reduce and prevent maternal anemia by increasing the diversity of the consumption of iron food sources, awareness of pregnant women to consume iron tablets, and the role of husband in encouraging pregnant women to consume iron tablets.
\end{abstract}

KEYWORDS: anemia, compliance in consuming iron tablets, nutrient intake

\begin{abstract}
ABSTRAK
Latar belakang: Salah satu masalah gizi yang banyak terjadi pada ibu hamil adalah anemia gizi, yang merupakan masalah gizi mikro terbesar dan tersulit diatasi di seluruh dunia. Hasil Riskesdas tahun 2010 menunjukkan 80,7\% wanita usia subur (WUS) yang hamil mendapat/membeli tablet besi, namun sebagian besar diketahui tidak patuh mengonsumsinya. Kekurangan besi dalam tubuh disebabkan kurangnya konsumsi makanan sumber zat besi dan ketidakpatuhan ibu hamil mengonsumsi tablet besi. Suplementasi
\end{abstract}

\footnotetext{
${ }^{1}$ Dinas Kesehatan Kabupaten Banyumas, Jl. RA. Wiryaatmaja No 4 Purwokerto Kabupaten Banyumas, e-mail: aripurwoko_wu@ yahoo.com

2 Bagian Obstetri dan Ginekologi RSUP Dr. Sardjito, Jl. Kesehatan, Yogyakarta, e-mail: dnurdiaty@yahoo.com

${ }^{3}$ Bagian Program Studi Gizi dan Kesehatan, Fakultas Kedokteran UGM, JI. Farmako Sekip Utara, Yogyakarta
} 
tablet besi dan perbaikan asupan zat gizi terutama sumber zat besi merupakan upaya penanggulangan anemia yang banyak dilakukan.

Tujuan: Mengetahui hubungan asupan zat gizi dan tingkat kepatuhan mengonsumsi tablet besi dengan kejadian anemia pada ibu hamil di Wilayah Kerja Puskesmas I Kembaran Kabupaten Banyumas.

Metode: Penelitian ini merupakan penelitian observasional (survey) dengan rancangan cross sectional dengan subjek penelitian 50 ibu hamil trimester III. Penelitian menggunakan pendekatan kuantitatif dan kualitatif.

Hasil: Persentase anemia pada ibu hamil sebesar 56,0\%. Hasil analisis multivariat hanya kepatuhan mengonsumsi tablet besi yang berhubungan bermakna ( $p=0,001, R P=3,7 ; 95 \% C l: 2,06-6,82)$ dengan kejadian anemia pada ibu hamil. Harga sumber makanan hewani yang mahal, keanekaragaman sumber makanan hewani yang terbatas, dan ketidaksukaan mengonsumsi sumber makanan hewani menyebabkan ibu hamil memilih sumber makanan nabati yang murah dan mudah didapat.

Kesimpulan: Asupan zat gizi terutama zat besi dan kepatuhan ibu hamil mengonsumsi tablet besi masih menjadi penyebab anemia pada ibu hamil. Oleh sebab itu, perlu dilakukan upaya penanggulangan dan pencegahan anemia ibu hamil dengan cara peningkatan keanekaragaman konsumsi bahan makanan sumber zat besi, kesadaran ibu hamil untuk mengonsumsi tablet besi, dan peran serta suami dalam mendorong ibu hamil mengonsumsi tablet besi.

KATA KUNCI: anemia, kepatuhan minum tablet besi, asupan zat gizi

\section{PENDAHULUAN}

Anemia merupakan masalah kesehatan masyarakat global baik di negara berkembang maupun di negara maju dengan konsekuensi besar bagi kesehatan manusia serta sosial ekonomi. Anemia terjadi pada semua tahap siklus hidup, namun lebih umum menyerang ibu hamil dan anak-anak (1). Ibu hamil yang mengalami anemia memiliki risiko kematian hingga 3,6 kali lebih besar dibandingkan dengan ibu hamil yang tidak mengalami (2).

Masalah yang sering terjadi pada ibu hamil yaitu tidak menyadari adanya peningkatan kebutuhan gizi selama hamil dan perilaku gizi yang salah sehingga terjadi ketidakseimbangan antara konsumsi dan kebutuhan. Pola makan yang salah pada ibu hamil membawa dampak terhadap terjadinya gangguan gizi, antara lain: anemia, pertambahan berat badan yang kurang pada ibu hamil, dan gangguan pertumbuhan janin (3).

Program suplementasi besi merupakan penanggulangan anemia yang paling banyak dilakukan, di samping upaya lain seperti fortifikasi bahan makanan dengan zat besi dan pendidikan gizi lewat strategi komunikasi, informasi, dan edukasi (4). Namun demikian, hal ini belum bisa mengatasi masalah anemia pada ibu hamil yang disebabkan oleh rendahnya kepatuhan ibu hamil untuk minum tablet besi (5).

Hasil Riskesdas tahun 2010 menunjukkan $80,7 \%$ wanita usia subur (WUS) yang hamil mendapat/membeli tablet besi. Sebanyak 18,0\% minum tablet besi dengan jumlah hari 90 atau lebih, $19,3 \%$ tidak minum tablet besi dan $15,3 \%$ yang menjawab tidak tahu. Ibu hamil tidak minum tablet Fe untuk mencegah anemia yang tinggal di pedesaan $(24,8 \%)$ lebih tinggi dibanding ibu yang tinggal di perkotaan $(14,1 \%)$ (6). Profil Kesehatan Puskesmas I Kembaran 2013 menunjukkan cakupan ibu hamil yang mendapat tablet $\mathrm{Fe} 1$ sebesar $98,03 \%$ (Banyumas: 95,78\%) dan Fe 3 sebanyak 89,26\% (Kabupaten Banyumas: 89,73\%). Prevalensi ibu hamil anemia yaitu 21,9\% lebih tinggi dari prevalensi anemia ibu hamil Kabupaten Banyumas (18,24\%), dengan prevalensi anemia lebih dari $20 \%$ sudah merupakan masalah kesehatan masyarakat di wilayah kerja Puskesmas I Kembaran (7). Penelitian ini dilakukan untuk mengetahui hubungan asupan zat gizi dan tingkat kepatuhan mengonsumsi tablet besi dengan kejadian anemia pada ibu hamil.

\section{BAHAN DAN METODE}

Penelitian ini merupakan penelitian observasional (survei) dengan rancangan potong 
lintang (cross sectional) yaitu rancangan penelitian yang mempelajari hubungan antara paparan (faktor penelitian) dan penyakit atau efek pada saat bersamaan, diukur menurut keadaan atau statusnya pada waktu dilakukan observasi (8). Penelitian ini menggunakan pendekatan secara kuantitatif dan kualitatif.

Penelitian ini dilaksanakan di Puskesmas I Kembaran, Kabupaten Banyumas selama 4 bulan yaitu dari bulan November 2013 hingga Februari 2014. Populasi dalam penelitian ini adalah 172 ibu hamil trimester III yang berada di wilayah kerja Puskesmas I Kembaran Kabupaten Banyumas. Pemilihan subjek untuk data kuantitatif menggunakan teknik simple random sampling sehingga didapatkan sampel sebesar 50 responden, sedangkan pemilihan subjek untuk data kualitatif menggunakan metode purposive sampling dengan pendekatan maximum variation sampling sehingga didapat sampel 21 informan. Informan terdiri dari informan utama yaitu subjek yang terlibat langsung dalam interaksi sosial yang diteliti dan informan pendukung subjek yaitu yang dapat memberikan informasi walaupun tidak langsung terlibat dalam interaksi sosial yang diteliti. Informan utama terdiri dari 8 ibu hamil. Informan pendukung yaitu keluarga terdekat/suami dari ibu hamil sejumlah 8 orang dan 5 orang petugas kesehatan.

Variabel bebas dalam penelitian ini adalah asupan zat gizi dan kepatuhan mengonsumsi tablet besi. Variabel terikat adalah anemia pada ibu hamil, sedangkan variabel luarnya adalah pendidikan ibu, umur ibu, jarak kelahiran, dan paritas.

Data kuantitatif diperoleh melalui wawancara dengan menggunakan kuesioner kepatuhan, kuesioner food recall $3 \times 24$ jam dengan waktu yang tidak berurutan dengan alat bantu ukuran rumah tangga (URT) dan alat pengukur hemoglobin $(\mathrm{Hb})$ darah, sedangkan data kualitatif diperoleh melalui wawancara mendalam (in-depth interview). Penelitian dilaksanakan setelah memperoleh Surat Kelaikan Etik (ethical clearence) dengan nomor: KE/FK/1134/EC tahun 2014. Analisis data menggunakan software program Stata Intercooled Versi 11.0 Universitas Gadjah Mada, Public Health CHR dengan langkah-langkah: analisis univariabel, bivariabel, dan multivariabel dengan menggunakan uji statistik chi-square dan uji regresi logistik.

\section{HASIL}

\section{Karakteristik responden}

Untuk studi kuantitatif latar belakang pendidikan responden terdiri dari sekolah dasar (SD), sekolah menengah pertama (SMP), dan sekolah menengah atas (SMA) sedangkan pekerjaan responden sebagian besar adalah ibu rumah tangga. Rentang umur responden berada antara 17-40 tahun. Karakteristik responden berdasarkan umur, pendidikan, dan pekerjaan ibu ditampilkan pada Tabel 1.

Tabel 1. Gambaran umum karakteristik subjek penelitian

\begin{tabular}{lc}
\hline \multicolumn{1}{c}{ Kelompok responden } & Jumlah \\
\hline Pendidikan ibu & \\
Dasar (SD, SMP) & 37 \\
Lanjut (SMA) & 13 \\
Pekerjaan & \\
Ibu rumah tangga & 48 \\
Karyawan swasta & 2 \\
Umur ibu & \\
$\quad$ Berisiko (>35 tahun dan $<20$ tahun) & 14 \\
Tidak berisiko & 36 \\
\hline
\end{tabular}

Untuk studi kualitatif latar belakang pendidikan informan utama terdiri dari SD, SMP, dan SMA, sedangkan pekerjaan informan utama adalah ibu rumah tangga. Latar belakang pendidikan informan pendukung adalah SD, SMA, dan sarjana muda (DIII dan DIV).

\section{Distribusi frekuensi responden berdasarkan variabel penelitian}

Tabel 2 menunjukkan bahwa 56\% responden menderita anemia. Untuk asupan zat gizi menunjukkan bahwa $60 \%$ responden asupan energinya kurang dari angka kecukupan gizi (AKG), 24\% responden asupan proteinnya kurang dari $A K G, 36 \%$ responden asupan zat besinya kurang dari AKG, dan $58 \%$ responden asupan vitamin $C$ nya kurang dari $A K G$. Untuk tingkat kepatuhan responden minum tablet besi menunjukkan bahwa $40 \%$ responden tidak patuh. Umur ibu yang berisiko untuk melahirkan sebanyak $28 \%$ responden. 
Jarak kelahiran dari kelahiran anak sebelumnya dan atau melahirkan pertama kali sebagian besar responden $\geq 2$ atau anak pertama yaitu $68 \%$. Jumlah anak yang dilahirkan (paritas) responden sebagian besar $\leq 2$ yaitu $90 \%$ dan untuk pendidikan ibu sebanyak $74 \%$ responden menempuh pendidikan dasar.

Tabel 2. Distribusi frekuensi responden berdasarkan variabel penelitian

\begin{tabular}{|c|c|c|}
\hline Variabel & $\begin{array}{l}\text { Frekuensi } \\
\text { (f) }\end{array}$ & $\begin{array}{c}\text { Persentase } \\
\text { (\%) }\end{array}$ \\
\hline \multicolumn{3}{|l|}{ Status anemia } \\
\hline Anemia & 28 & 56,0 \\
\hline Tidak anemia & 22 & 44,0 \\
\hline \multicolumn{3}{|l|}{ Asupan enerqi } \\
\hline Kurang & 30 & 60,0 \\
\hline Baik & 20 & 40,0 \\
\hline \multicolumn{3}{|l|}{ Asupan protein } \\
\hline Kurang & 12 & 24,0 \\
\hline Baik & 38 & 76,0 \\
\hline \multicolumn{3}{|l|}{ Asupan besi } \\
\hline Kurang & 18 & 36,0 \\
\hline Baik & 32 & 64,0 \\
\hline \multicolumn{3}{|l|}{ Asupan vitamin $\mathrm{C}$} \\
\hline Kurang & 29 & 58,0 \\
\hline Baik & 21 & 42,0 \\
\hline \multicolumn{3}{|l|}{ Tingkat kepatuhan minum } \\
\hline tablet besi & 20 & 40,0 \\
\hline Tidak patuh & 30 & 60,0 \\
\hline \multicolumn{3}{|l|}{ Patuh } \\
\hline \multicolumn{3}{|l|}{ Umur ibu } \\
\hline Berisiko & 14 & 28,0 \\
\hline Tidak berisiko & 36 & 72,0 \\
\hline \multicolumn{3}{|l|}{ Pendidikan ibu } \\
\hline Dasar & 37 & 74,0 \\
\hline Lanjut & 13 & 26,0 \\
\hline \multicolumn{3}{|l|}{ Jarak kelahiran (tahun) } \\
\hline$<2$ & 16 & 32,0 \\
\hline$\geq 2$ atau anak pertama & 34 & 68,0 \\
\hline \multicolumn{3}{|l|}{ Paritas (anak) } \\
\hline$>2$ & 5 & 10,0 \\
\hline$\leq 2$ & 45 & 90,0 \\
\hline
\end{tabular}

Pada penelitian ini dilakukan recall makanan terhadap responden. Analisis food recall $3 \times 24$ jam diperoleh hasil rata-rata asupan zat gizi responden dibandingkan dengan AKG. Tabel 3 diketahui bahwa rata-rata asupan energi responden dibandingkan AKG sebesar $91,8 \%$, rata-rata asupan protein dibandingkan AKG sebesar $98,66 \%$, rata-rata asupan zat besi dibandingkan AKG sebesar $124 \%$ untuk asupan zat besi yang berasal dari makanan dan suplemen tablet besi, sedangkan $11,40 \%$ untuk asupan zat besi yang hanya berasal dari asupan makanan saja dan rata-rata asupan vitamin C dibandingkan AKG sebesar 70,67\%.

Hubungan asupan zat gizi, tingkat kepatuhan mengonsumsi tablet besi, umur ibu, pendidikan ibu, jarak kelahiran, dan paritas dengan kejadian anemia

Berdasar Tabel 4 diketahui bahwa dari semua variabel yang diteliti hanya asupan zat besi, tingkat kepatuhan mengonsumsi tablet besi, dan umur ibu yang mempunyai hubungan bermakna dengan kejadian anemia pada ibu hamil, sedangkan asupan energi, asupan protein, asupan vitamin C, pendidikan ibu, jarak kelahiran, dan paritas tidak mempunyai hubungan bermakna dengan kejadian anemia pada ibu hamil.

Berdasarkan data kualitatif dapat diketahui berbagai informasi tentang pengetahuan anemia, asupan zat gizi ibu hamil, dan kepatuhan ibu hamil dalam mengonsumsi tablet besi yang belum terungkap yang mendukung dan menguatkan hasil dari analisis kuantitatif.

Berdasarkan hasil wawancara mendalam diketahui bahwa informan utama ada yang

Tabel 3. Asupan zat gizi rata-rata responden dibandingkan dengan angka kecukupan gizi (AKG)

\begin{tabular}{lccc}
\hline \multicolumn{1}{c}{ Zat gizi } & $\begin{array}{c}\text { AKG ibu hamil } \\
\text { trimester 3 }\end{array}$ & $\begin{array}{c}\text { Rata-rata asupan zat gizi } \\
\text { responden }\end{array}$ & $\begin{array}{c}\text { Rata-rata asupan zat gizi } \\
\text { dibandingkan AKG }\end{array}$ \\
\hline Energi (kkal) & 2200 & 1981,22 & $91,8 \%$ \\
$\quad$ Umur 19-29 tahun & 2100 & & \\
Umur 30-49 tahun & 67 & 66,1 & $98,66 \%$ \\
Protein (gram) & 39 & 48,7 (dengan tablet besi) & $124,87 \%$ \\
Zat besi (mg) & & 11,4 (tanpa tablet besi) & $29,10 \%$ \\
& 85 & 60,1 & $70,67 \%$ \\
Vitamin C (mg) & &
\end{tabular}


Tabel 4. Hubungan asupan zat gizi, tingkat kepatuhan mengonsumsi tablet besi, umur ibu, pendidikan ibu, jarak kelahiran, dan paritas dengan kejadian anemia ibu hamil

\begin{tabular}{|c|c|c|c|c|c|c|c|c|}
\hline \multirow{2}{*}{ Variabel } & \multicolumn{2}{|c|}{ Anemia } & \multicolumn{2}{|c|}{ Tidak anemia } & \multirow{2}{*}{$\chi^{2}$} & \multirow{2}{*}{$\mathbf{p}$} & \multirow{2}{*}{ PR } & \multirow{2}{*}{$95 \% \mathrm{Cl}$} \\
\hline & $\mathbf{n}$ & $\%$ & $\mathbf{N}$ & $\%$ & & & & \\
\hline \multicolumn{9}{|l|}{ Asupan energi } \\
\hline Kurang & 20 & 66,67 & 10 & 33,3 & 3,46 & 0,063 & 1,6 & $0,92-3,01$ \\
\hline Baik & 8 & 40,00 & 12 & 60,00 & & & & \\
\hline \multicolumn{9}{|l|}{ Asupan protein } \\
\hline Kurang & 8 & 66,67 & 4 & 33,33 & 0,72 & 0,30 & 1,27 & $0,76-2,09$ \\
\hline Baik & 20 & 52,63 & 18 & 47,37 & & & & \\
\hline \multicolumn{9}{|l|}{ Asupan besi } \\
\hline Kurang & 18 & 100,0 & 0 & 0,00 & 22,09 & $0,000^{*}$ & 3,2 & $1,91-5,35$ \\
\hline Baik & 10 & 31,25 & 22 & 68,75 & & & & \\
\hline \multicolumn{9}{|l|}{ Asupan vitamin C } \\
\hline Kurang & 18 & 62,07 & 11 & 37,93 & 1,03 & 0,310 & 1,3 & $0,77-2,21$ \\
\hline Baik & 10 & 47,62 & 11 & 52,38 & & & & \\
\hline \multicolumn{9}{|c|}{ Tingkat mengonsumsi tablet besi } \\
\hline Tidak Patuh & 20 & 100 & 0 & 0 & & & & \\
\hline Patuh & 8 & 26,67 & 22 & 73,33 & 26,19 & $0,000^{*}$ & 3,75 & $2,07-6,78$ \\
\hline \multicolumn{9}{|l|}{ Umur ibu } \\
\hline Berisiko & 11 & 78,57 & 3 & 21,43 & 4,02 & 0,044 & 1,7 & $1,07-2,58$ \\
\hline Tidak berisiko & 17 & 47,22 & 19 & 52,78 & & & & \\
\hline \multicolumn{9}{|l|}{ Pendidikan ibu } \\
\hline Dasar & 23 & 62,16 & 14 & 37,84 & 2,19 & 0,12 & 1,6 & $0,78-3,36$ \\
\hline Lanjut/menengah & 5 & 38,46 & 8 & 61,54 & & & & \\
\hline \multicolumn{9}{|l|}{ Jarak kelahiran (tahun) } \\
\hline$<2$ & 3 & 75,00 & 1 & 25,00 & & & & \\
\hline$\geq 2$ atau anak pertama & 25 & 54,35 & 21 & 45,5 & 0,64 & 0,40 & 1,38 & $0,74-2,58$ \\
\hline \multicolumn{9}{|l|}{ Paritas (anak) } \\
\hline$>2$ & 3 & 60,00 & 2 & 40,00 & 0,036 & 0,62 & 1,1 & $0,50-2,31$ \\
\hline$\leq 2$ & 25 & 55,56 & 20 & 44,44 & & & & \\
\hline
\end{tabular}

memahami dan tidak memahami pengertian anemia pada ibu hamil. Informan utama yang memahami pengertian anemia menyebutkan bahwa seorang ibu hamil dikatakan anemia apabila $\mathrm{Hb}$ di bawah $11 \mathrm{~g} \%$. Informan yang tidak memahami pengertian anemia, tidak bisa menyebutkan batasan anemia ibu hamil. Informan mempunyai pemahaman yang sama tentang penyebab dan gejala anemia. Penyebab anemia pada ibu hamil adalah makanan yang kurang bergizi dan tidak minum tablet besi, sedangkan gejala anemia adalah lemah, letih, lesu, pusing, dan berkunang-kunang.

Berdasarkan hasil wawancara mendalam, informan mengatakan bahwa selama hamil membutuhkan asupan energi dengan cara makan bergizi, menambah jumlah porsi, dan jenis makanan. Sementara itu, ada informan lain yang mengatakan bahwa selama hamil mereka makan seperti biasa seperti saat sebelum hamil. Pemahaman yang berbeda ini menyebabkan ibu hamil mengonsumsi energi sama atau kurang dari biasa untuk memenuhi asupan energinya, sehingga menyebabkan rata-rata asupan energi ibu hamil kurang dari AKG. Asupan energi responden sebagian besar berasal dari karbohidrat. Karbohidrat bukan sumber zat besi, sehingga tidak mempengaruhi status anemia.

Kebutuhan protein selama kehamilan penting untuk mendukung pertumbuhan dan perkembangan janin. Informan memahami bahwa protein berguna untuk kesehatan janin yang dikandungnya. Harga bahan makanan sumber protein hewani yang mahal, faktor ekonomi keluarga, ketersediaan bahan makan sumber protein hewani yang kurang atau tidak tersedia di sekitar tempat tinggal, perasaan bosan, dan tidak suka terhadap lauk hewani menjadi penyebab asupan protein hewani informan utama kurang. Hal ini menyebabkan infoman memilih ke sumber protein nabati yang lebih murah. 
Informan memahami asupan zat besi penting untuk mencegah anemia selama kehamilan. Angka kejadian anemia masih cukup tinggi. Hal ini disebabkan asupan zat besi yang berasal dari makanan, terutama sumber hewani masih terbilang kurang. Kebutuhan zat besi responden sebagian besar berasal dari suplementasi tablet besi. $\mathrm{Di}$ samping itu, kejadian anemia disebabkan informan lebih memilih makanan sumber nabati (non-heme) yang lebih murah dan mudah didapat, akan tetapi memiliki bioavailabilitas zat besi yang rendah.

Konsumsi buah-buahan sebagai sumber utama vitamin $\mathrm{C}$ menjadi kendala. Kendala ini disebabkan harga buah-buahan yang relatif mahal, ketersediaan buah-buahan yang kurang di lingkungan sekitar, dan ketergantungan terhadap musim untuk buahbuahan tertentu serta tidak menyukai beberapa jenis buah. Hal ini menyebabkan rata-rata asupan vitamin C informan kurang dibandingkan dengan AKG.

Berdasarkan hasil wawancara diketahui bahwa informan utama (informan ibu hamil anemia) tidak patuh mengonsumsi tablet besi disebabkan lupa, malas minum, bau amis, dan tidak bisa menelannya, sedangkan untuk informan utama (ibu hamil tidak anemia) patuh mengonsumsi tablet besi disebabkan takut kalau menderita anemia dan takut janin yang dikandungnya tidak sehat.
Analisis regresi logistik hubungan asupan zat gizi dan tingkat kepatuhan mengonsumsi tablet besi dengan kejadian anemia

Analisis multivariabel dilakukan untuk mengetahui pengaruh variabel bebas (asupan zat gizi dan kepatuhan mengonsumsi tablet besi) dengan variabel terikat (anemia pada ibu hamil) dengan mengikutsertakan variabel luar yaitu umur ibu. Model 3 sebagai model yang secara statistik lebih mudah menjelaskan bahwa ada hubungan bermakna tingkat kepatuhan mengonsumsi tablet besi dengan kejadian anemia pada ibu hamil ditunjukkan dengan $p=0,0001$ (PR=3,7, 95\% Cl: 2,06-6,82, R2: 12,80). Hal ini berarti ibu hamil tidak patuh mengonsumsi tablet besi mempunyai risiko 3,7 kali lebih besar untuk menderita anemia dan tingkat kepatuhan mengonsumsi tablet besi memberikan kontribusi sebesar $12,8 \%$ untuk terjadinya anemia pada ibu hamil. Hasil analisis regresi logistik ditampilkan pada Tabel 5.

\section{BAHASAN}

\section{Hubungan asupan energi dengan kejadian anemia}

Hasil penelitian menunjukkan bahwa asupan energi responden sebagian besar berasal dari

Tabel 5. Analisis regresi logistik hubungan asupan zat gizi dan tingkat kepatuhan mengonsumsi tablet besi dengan kejadian anemia pada ibu hamil

\begin{tabular}{|c|c|c|c|}
\hline Variabel & $\begin{array}{c}\text { Model } 1 \\
\operatorname{RP}(95 \% \mathrm{Cl}) \\
\text { (p) }\end{array}$ & $\begin{array}{c}\text { Model } 2 \\
\operatorname{RP}(95 \% \mathrm{Cl}) \\
\text { (p) }\end{array}$ & $\begin{array}{c}\text { Model } 3 \\
\operatorname{RP}(95 \% \mathrm{Cl}) \\
\text { (p) }\end{array}$ \\
\hline \multicolumn{4}{|c|}{ Kepatuhan minum tablet besi } \\
\hline Tidak patuh & $3,61(1,94-6,72)$ & $3,6(1,97-6,71)$ & $3,7(2,06-6,82)$ \\
\hline & 0,0001 & 0,0001 & 0,0001 \\
\hline Patuh & 1 & 1 & 1 \\
\hline \multicolumn{4}{|l|}{ Asupan zat besi } \\
\hline Kurang & $\begin{array}{c}1,01(0,93-1,09 ;) \\
0,885\end{array}$ & & \\
\hline Baik & 1 & & \\
\hline \multicolumn{4}{|l|}{ Umur ibu } \\
\hline Berisiko & $\begin{array}{c}1,11(0,81-1,54) \\
0,507\end{array}$ & $\begin{array}{c}1,1(0,81-1,54) \\
0,507\end{array}$ & \\
\hline Tidak berisiko & 1 & 1 & \\
\hline $\mathrm{R}^{2}$ & 12,88 & 12,88 & 12,80 \\
\hline
\end{tabular}


sumber karbohidrat. Rata-rata konsumsi energi adalah $1.981,22 \mathrm{kkal}$ dan persentase asupan energi dibandingkan dengan AKG sebesar 91,8\% (Tabel 3). Hal ini menunjukkan asupan energi ibu hamil masih kurang.

Uji statistik menunjukkan tidak ada hubungan yang bermakna antara tingkat kecukupan energi dengan kejadian anemia $(p=0,063)$ (Tabel 4). Tidak adanya hubungan bermakna antara asupan energi dengan kejadian anemia diasumsikan bahwa asupan energi responden sebagian besar berasal dari sumber karbohidrat. Karbohidrat bukan sumber zat besi sehingga tidak mempengaruhi status anemia (9). Walau bukan sumber zat besi, karbohidrat yang cukup akan mencegah penggunaan protein untuk energi (sebagai penghemat protein). Di antara 30 ibu hamil yang asupan energinya kurang, masih terdapat $66,67 \%$ yang mengalami anemia (Tabel 2, Tabel 4), sesuai dengan penelitian yang menunjukkan pada ibu hamil dengan anemia gizi besi memiliki asupan energi secara signifikan lebih rendah dari yang tidak anemia dan asupan zat besi dari diet juga secara signifikan lebih sedikit (10).

Berdasakan hasil analisis kualitatif diketahui bahwa pemahaman yang berbeda tentang pengetahuan dan praktik makan menyebabkan asupan energi informan kurang dari AKG. Berdasarkan hasil food recall $3 \times 24$ jam, diketahui bahwa asupan energi informan sebagian besar berasal dari karbohidrat, sehingga tidak mempengaruhi status anemia.

\section{Hubungan asupan protein dengan kejadian anemia}

Hasil penelitian menunjukkan 12 (24\%) responden memiliki asupan protein kurang dari AKG (Tabel 2) dan 66,67\% menderita anemia (Tabel 4). Hasil penelitian ini menunjukan bahwa rata-rata konsumsi protein responden adalah 66,1 gram dan asupan protein dibandingkan dengan AKG sebesar $98,66 \%$ (Tabel 3). Hal ini menunjukkan asupan protein ibu hamil sudah baik.

Uji statistik membuktikan tidak ada hubungan yang bermakna antara asupan protein dengan kejadian anemia pada ibu hamil $(p=0,30)$ (Tabel 4). Hal ini diduga disebabkan asupan protein yang dikonsumsi responden sebagian besar berasal dari protein nabati. Untuk membantu penyerapan protein nabati dibutuhkan vitamin C. Suatu penelitian menyatakan bahwa protein nabati merupakan sumber zat besi non-heme yang dalam proses penyerapannya lebih efektif bila ada vitamin C, sedangkan protein hewani merupakan sumber zat besi heme yang bisa langsung diabsorpsi oleh tubuh (11). Protein berperan penting dalam transportasi zat besi dalam tubuh. Penelitian lain menyatakan bahwa kekurangan asupan protein akan menyebabkan transportasi zat besi terganggu, sehingga menyebabkan defisiensi zat besi (anemia).

Hasil analisis kualitatif diketahui bahwa mahalnya harga lauk hewani, keanekaragaman bahan makan sumber protein hewani yang kurang di sekitar lingkungan tempat tinggal, bosan, dan tidak suka lauk hewani menyebabkan responden lebih memilih ke sumber protein nabati yang relatif murah dan mudah didapat.

\section{Hubungan asupan zat besi dengan kejadian anemia ibu hamil}

Hasil penelitian menunjukkan 18 (36\%) responden memiliki asupan zat besi kurang dari AKG dan semua menderita anemia (Tabel 4). Rata-rata konsumsi zat besi responden dari makanan sebesar $11,4 \mathrm{mg}$ dan dari tablet besi sebesar $48,7 \mathrm{mg}$. Asupan zat besi yang berasal dari makanan dibanding AKG sebesar $29,10 \%$. $\mathrm{Hal}$ ini menunjukkan asupan zat besi ibu hamil sangat kurang, sedangkan bila asupan zat besi digabungkan antara asupan dari makanan dan dari suplemen zat besi, maka tingkat konsumsi rata-rata zat besi sebesar $124,87 \%$ dibandingkan AKG (Tabel 3). Hal ini menunjukkan asupan zat besi lebih dari AKG.

Uji statistik menunjukkan adanya hubungan bermakna antara asupan zat besi dengan kejadian anemia pada ibu hamil $(p=0,001)$. Hasil penelitian menunjukkan bahwa ibu hamil yang asupan zat besinya kurang mempunyai risiko 3,2 kali untuk menderita anemia (Tabel 4). Hal ini diasumsikan bahwa asupan zat besi responden yang berasal dari makanan kurang dan sebagian asupan zat besi berasal dari suplementasi zat besi serta kepatuhan 
responden untuk mengonsumsi tablet besi masih rendah yang memungkinkan terjadinya anemia gizi besi. Di samping itu, responden mempunyai kebiasaan untuk mengonsumsi sumber protein nabati (zat besi non heme). Sumber zat non heme mempunyai bioavailabilitas yang rendah. DeMaeyer menyatakan bahwa zat besi merupakan mikronutrien yang esensial bagi tubuh. Sumber zat besi berasal dari asupan makanan dan suplementasi zat besi. Sumber zat besi dari makanan berasal dari heme dan non-heme (12). Zat besi heme merupakan penyusun hemoglobin dan mioglobin yang akan langsung diabsorpsi oleh tubuh, sedangkan zat besi non-heme membutuhkan vitamin $\mathrm{C}$ dalam proses absorpsinya. Hal yang sama disebutkan bahwa penyebab utama anemia defisiensi zat besi adalah konsumsi zat gizi yang tidak memadai (11). Banyak orang bergantung hanya pada makanan nabati yang memiliki absorpsi terhadap zat besi yang rendah dan terdapat beberapa zat dalam makanan tersebut yang menghambat absorpsi zat besi.

Hasil analisis kualitatif diketahui bahwa asupan zat besi yang berasal dari makanan terutama sumber hewani (heme) masih tergolong kurang. Kebutuhan zat besi selama hamil sebagian besar berasal dari suplemen tablet besi. Di samping itu, informan lebih memilih makanan sumber nabati (non-heme) yang relatif murah dan mudah didapat, akan tetapi memiliki bioavailabilitas zat besi yang rendah.

\section{Hubungan asupan vitamin $\mathrm{C}$ dengan kejadian anemia ibu hamil}

Hasil penelitian menunjukkan 29 (58\%) responden memiliki asupan vitamin $C$ kurang dari AKG (Tabel 2) dan 62,1\% menderita anemia (Tabel 4). Rata-rata konsumsi vitamin $C$ responden sebesar $60,1 \mathrm{mg}$ dan persentase asupan vitamin $C$ dibandingkan dengan AKG adalah 70,67\% (Tabel 3). Hal ini menunjukkan asupan vitamin $C$ ibu hamil kurang dibandingkan AKG.

Penelitian ini menunjukkan tidak ada hubungan bermakna antara tingkat konsumsi vitamin $C$ dan kejadian anemia pada ibu hamil $(p=0,310)$ (Tabel 4). Tidak adanya hubungan ini diasumsikan asupan vitamin $\mathrm{C}$ kurang dibandingkan dengan
AKG. Selain itu, vitamin $C$ yang berfungsi sebagai zat yang membantu proses penyerapan zat besi akan lebih efektif bila disertai dengan konsumsi sumber zat besi yang tinggi. Fasilitator absorpsi zat besi adalah asam askorbat (vitamin $\mathrm{C}$ ) yang dapat meningkatkan absorpsi zat besi non heme secara signifikan $(11,13)$. Fishman menyatakan bahwa vitamin $C$ berperan dalam penyerapan zat besi dalam usus dan mobilisasi dari penyimpanan zat besi dalam feritin. Konsumsi $25-75 \mathrm{mg}$ vitamin $C$ dapat meningkatkan penyerapan empat kali zat besi non-heme.

Fungsi vitamin $\mathrm{C}$ menjadi tidak berarti apabila tidak disertai dengan konsumsi pangan sumber zat besi yang tinggi. Penelitian lain menyatakan bahwa untuk menurunkan prevalensi anemia dan defisiensi zat besi perlu diperhatikan keragaman hayati tinggi zat besi, pengenalan sumber makanan dengan bioavaibilitas zat besi yang tinggi, konsumsi buah dan sayur yang mengandung vitamin C (14).

Hasil analisis kualitatif diketahui bahwa mahalnya harga buah, keberadaan beberapa buah bersifat musiman, keanekaragaman buah di lingkungan sekitar terbatas, jauh dari pasar, dan tidak menyukai buah tertentu menyebabkan konsumsi buah kurang. Hal ini menyebabkan asupan vitamin C informan rata-rata di bawah AKG.

\section{Hubungan umur ibu dengan kejadian anemia pada ibu hamil}

Dari 14 ibu hamil yang umurnya berisiko (Tabel 2), terdapat 11 ibu hamil yang menderita anemia $(78,57 \%)$ dan 3 ibu hamil yang tidak menderita anemia $(21,43 \%)$. Sebanyak 36 ibu hamil yang umurnya tidak berisiko, terdapat 17 ibu hamil yang menderita anemia $(47,22 \%)$ (Tabel 4$)$.

Pada penelitian ini menunjukkan adanya hubungan bermakna antara tingkat kepatuhan minum tablet besi dengan kejadian anemia pada ibu hamil $(p=0,045)$. Nilai $P R=1,7$ menunjukkan umur ibu yang berisiko mempunyai risiko menderita anemia 1,7 kali (Tabel 4). Kondisi ini diasumsikan bahwa umur ibu hamil yang berisiko sebagian besar menderita anemia. Hal ini disebabkan ibu hamil umur berisiko di bawah 20 tahun sedang dalam masa pertumbuhan yang membutuhkan zat 
besi lebih banyak untuk mendukung pertumbuhan diri sendiri dan di saat yang bersamaan janin yang dikandungnya juga membutuhkan zat besi unuk pertumbuhannya. Sementara itu, ibu hamil umur berisiko di atas 35 tahun dimungkinkan berkaitan dengan paritas yang tinggi dan jarak kelahiran yang dekat sehingga tidak mempunyai kesempatan untuk memperbaiki cadangan zat besi di dalam tubuh dan berisiko untuk kekurangan zat besi, sehingga menderita anemia. Hasil penelitian ini sejalan dengan penelitian yang dilakukan di India yang mengatakan bahwa prevalensi anemia lebih tinggi ditemukan pada ibu hamil usia di atas 30 tahun (15), sedangkan penelitian yang dilakukan di Kota Bogor menyatakan bahwa tidak ada hubungan antara umur ibu dengan kejadian anemia pada ibu hamil (16).

\section{Hubungan kepatuhan minum tablet besi dengan kejadian anemia pada ibu hamil}

Hasil penelitian menunjukkan bahwa 20 $(40 \%)$ responden yang tidak patuh mengonsumsi tablet besi semua menderita anemia. Penelitian ini menunjukkan adanya hubungan bermakna antara tingkat kepatuhan minum tablet besi dengan kejadian anemia pada ibu hamil $(p=0,001)$. Hasil penelitian juga menunjukkan bahwa ibu hamil yang tidak patuh mengonsumsi tablet besi mempunyai risiko 3,7 kali lebih besar untuk menderita anemia (Tabel 4). Hal ini terjadi diasumsikan ketidakpatuhan responden dalam mengonsumsi tablet besi. Penelitian lain menyatakan adanya kecenderungan bahwa semakin kurang patuh mengonsumsi tablet besi, maka akan semakin tinggi kejadian anemia (16).

Ketidakpatuhan responden disebabkan tidak teratur dalam minum besi, lupa mengonsumsi tablet besi, menolak mengonsumsi tablet besi karena tablet susah ditelan, dan kurangnya dukungan suami untuk mendorong ibu hamil untuk mengonsumsi tablet besi. Penelitian lain menyatakan bahwa pengawasan suami terhadap ibu hamil dalam hal minum tablet besi telah mengurangi kelupaan ibu hamil untuk minum tablet besi. Lupa merupakan faktor penting yang menurunkan kepatuhan minum tablet besi (17). Lebih lanjut dalam penelitian tersebut menyatakan bahwa pemberian tablet besi kepada ibu hamil dengan pengawasan suami dapat meningkatkan kepatuhan minum tablet besi (kemungkinan patuh 8,5 kali) dan meningkatkan kadar $\mathrm{Hb}$. Selain itu, kepatuhan ibu hamil dalam mengonsumsi tablet besi dengan pengawasan suami lebih tinggi daripada tanpa pengawasan suami.

Berdasarkan penelitian kualitatif diketahui bahwa ketidakpatuhan konsumsi tablet besi disebabkan tidak teratur minum, lupa, tablet susah ditelan, dan kurangnya dukungan suami untuk mendorong ibu hamil dalam mengonsumsi tablet besi.

\section{KESIMPULAN DAN SARAN}

Penelitian ini menunjukkan bahwa asupan zat besi yang rendah, umur ibu berisiko, dan ketidakpatuhan ibu hamil mengonsumsi tablet besi menjadi penyebab anemia pada ibu hamil. Perlu dilakukan suatu upaya penanggulangan dan pencegahan anemia secara lintas sektoral dan lintas program. Hal ini dapat dilakukan melalui program perbaikan kualitas konsumsi pangan seperti penganekaragaman bahan makanan sumber zat besi, distribusi bahan makanan yang merata, pemberdayaan ekonomi keluarga, peningkatan kesadaran ibu hamil agar patuh untuk mengonsumsi tablet besi disertai dengan peningkatan peran serta suami dalam mendorong ibu hamil mengonsumsi tablet besi. Peran petugas kesehatan juga diperlukan dalam peningkatan kesadaran penyuluhan dan konseling gizi dan kesehatan kepada ibu hamil, anggota keluarga dan masyarakat.

\section{RUJUKAN}

1. Conrad M. Iron deficiency anemia [Internet]. 2006 [cited 2012 Oct 12]. Available from: medicine. medscape.com.http://www.com. comMED/Topic1188

2. Rush D. Nutrition and maternal mortality in developing world. Am J Clin Nutr. 2000;72(Suppl):212S - 40S.

3. Ojofeitimi E, Ogunjuyigbe P, Sanusi R, Orji E, Akinlo A, Liasu $S$, et al. Poor dietary intake of energy and retinol among pregnant women: implications for pregnancy outcome in Southwest Nigeria. Pak J Nutr. 2008;7(3):480-4. 
4. Departemen Kesehatan RI. Pedoman pemberian besi bagi petugas. Jakarta: Departemen Kesehatan RI; 1996.

5. Schultink W, Ree M, Matulessi P, Gross R. Low compliance with an iron supplementation program: a study pregnant women in Jakarta, Indonesia. Am J Clin Nutr. 1993;57:135-9.

6. Departemen Kesehatan RI. Laporan nasional riset kesehatan dasar (Riskesdas) tahun 2010. Jakarta: Badan Penelitian dan Pengembangan Kesehatan Depkes RI; 2010.

7. Puskesmas I Kembaran Kabupaten Banyumas. Profil kesehatan Puskesmas I Kembaran Kab. Banyumas Tahun 2013. Banyumas: Puskesmas I Kembaran Kab. Banyumas; 2014.

8. Sastroasmoro S, Ismael S. Dasar-dasar metodologi penelitian klinis. Jakarta: Bina Rupa Aksara; 1995.

9. Almatsier S. Prinsip dasar ilmu gizi. Jakarta: PT. Gramedia Pustaka Utama; 2001.

10. School T. Iron status during pregnancy : setting the stage for mother and infanf. Am J Clin Nutr. 2005;81(suppl):1218S - 22S.

11. Vijayaraghavan $\mathrm{K}$. Anemia karena defisiensi zat besi Dalam gizi kesehatan masyarakat. Gibney, Michael.J. et al, editor. Jakarta: Penerbit Buku Kedokteran EGC; 2009.
12. DeMaeyer E. Pencegahan dan pengawasan anemia defisiensi besi. Jakarta: Widya Medika; 1993.

13. Fishman S, Christian P, West PJ. The role of vitamins in the prevention and control of anaemia. J Public Heal Nutr. 3AD;20:12550.

14. Tatatala S, Svanberg U, Mduma B. Low dietary iron availability is a major cause of anemia: a nutrition survey in the Lindi District Of Tanzania1-3. Am J Clin Nutr. 1998;68:171-8.

15. Agarwal K, Varsha C, Agarwal V, Agarwal A, Rajeev K, Sharma M. Prevalence and determinants of anemia in pregnancy at Private Hospital Of Bareilly District. NJIRM. 2011;2(4):29-32.

16. Herlina N. Faktor risiko kejadian anemia pada ibu hamil di wilayah kerja Puskesmas Bogor [Internet]. 2012 [cited 2012 Oct 12]. Available from: http://alijeco.blogspot.co.id/2008/05/ faktor-resiko-kejadian-anemia-pada-ibu.html

17. Hadi $\mathrm{H}$, Lestariana W, Widagdo D. Pengaruh suplementasi tablet $F$ e dengan supervisi suami pada ibu hamil terhadap umur kehamilan di Kabupaten Bantul. J Gizi Klin Indones. 2005;1:22-7. 